\title{
ВЛИЯНИЕ КЛИМАТИЧЕСКОЙ ИЗМЕНЧИВОСТИ НА ФИТОПЛАНКТОННЫЕ КОМПЛЕКСЫ ШЕРНЕВСКОГО ПИТЬЕВОГО ВОДОХРАНИЛИЩА (ЮЖНЫЙ УРАЛ)
}

\author{
А.О. Гаязова, С.М. Абдуллаев \\ Южно-Уральский государственный университет, Россия \\ Поступила в редакичию 20 декабря 2018 г.
}

\begin{abstract}
Аннотация: В работе на основе круглогодичных альгологических и гидрометеорологических наблюдений с 1984 по 2015 год исследуется влияние гидротермического режима и ветровых условий на численность и видовой состав фитопланктона Шершневского питьевого водохранилища. Установлено, что к настоящему времени наблюдается рост общей численности фитопланктона в 25 раз в сентябре-мае. Наиболее значимые изменения отмечены в последнем десятилетии, когда: 1) произошло резкое, в 10-20 раз, увеличение численности зеленых и синезеленых водорослей в подледный период, совпавшее с заметным охлаждением температуры воды на $0,5^{\circ} \mathrm{C} ; 2$ ) потепление воды в мае на $1,5^{\circ} \mathrm{C}$ привело к более раннему максимуму вегетации зеленых водорослей. Анализ реакции отдельных видов на климатическую изменчивость, включая круглогодичную вегетацию ряда массовых летних видов и перестройку доминирующих комплексов, свидетельствует об избыточном количестве биогенных веществ, поступающих в водохранилище.
\end{abstract}

Ключевые слова: Шершневское водохранилище, доминирующие виды, климатические изменения, эвтрофикация водохранилищ.

\section{Influence of climate variability on phytoplankton complexes of the Shershnevskoye Drinking Reservoir (South Urals)}

\section{A. O. Gayazova, S. M. Abdullaev}

\begin{abstract}
Hydrothermal and wind-stress conditions' influence on abundance and composition of Shershnevskoye reservoir algae species is studied using annual algological and hydrometeorological observation's data sets for 1984-2015 period. Analysis indicated the growth of phytoplankton abundance by 25 times in September-May. The most significant changes occurred in the last decade, when: 1) Rapid growth of blue-green and green algae abundance in winter period coincided with a noticeable cooling of the water temperature by 0,5 degrees; 2 ) Increasing of water temperature by 1,5 degrees led to the earlier green algae vegetation maximum. All year round vegetation of summer dominant algae species and shifts in dominant algae complexes indicated the excess of nutrient inflow into the reservoir.
\end{abstract}

Key words: Shershnevskoye reservoir, dominant algae species, climate change, eutrophication of reservoirs.

\section{ВВЕДЕНИЕ}

Данная статья посвящена оценке влияния изменения климата на развитие фитопланктонного сообщества Шершневского питьевого водохранилища (ШПВ). Выбранный для этих оценок период с 1984 по 2015 год объясняется тем, что ШПВ возведено в 1969 году в среднем течении реки Миасс к западу от городской черты Челябинска и

(ㄷ Гаязова А. О., Абдуллаев С.М., 2019 до начала 80-х водохранилище проходило стадию стабилизации береговых процессов и ложа. Рост продуктивности в это время шел при умеренном поступлении биогенных элементов с водосборной площади реки, занятой землями лесного фонда и сельскохозяйственного назначения. В 1985 году наступила стадия освоения прибрежных территорий садоводческими товариществами, а в начале этого века развернулось строительство городских микрорайонов на западном берегу водохранили- 

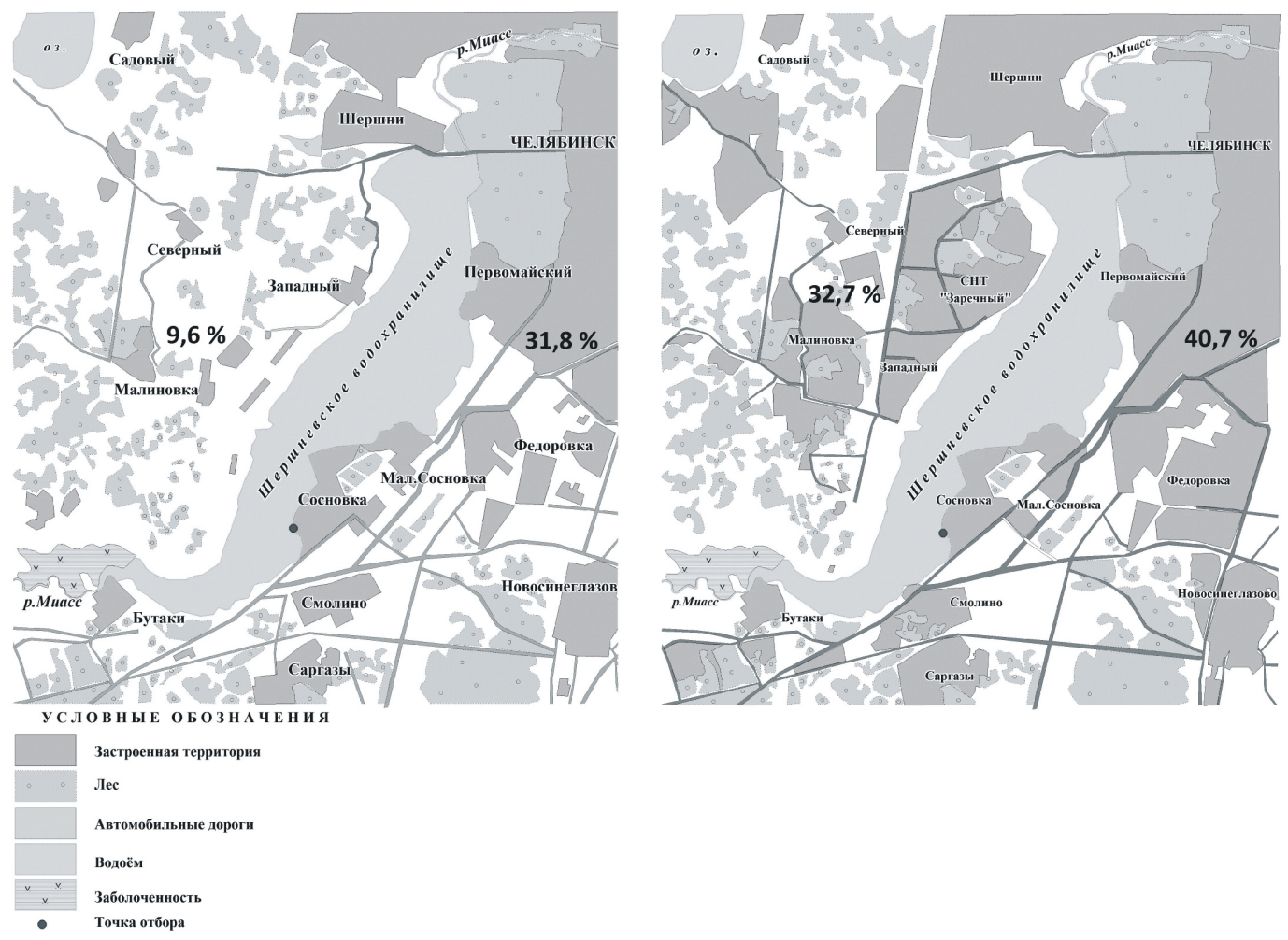

Puc. 1. Изменения, произошедшие на водозаборе Шершневского водохранилища за 30 лет: процент застроенности левого и правого берегов в 1985 и 2015 годах

ща. Размах изменений, произошедших за 30 лет на берегах водохранилища, хорошо виден на представленных ниже картосхемах (рис. 1).

В публикации [3] мы предположили, что заметные изменения доминантных комплексов фитопланктона ШПВ - это комплексный отклик на потепление регионального климата и увеличение поступления биогенных веществ со стоком от прибрежных селитебных территорий. В этой статье, используя данные многолетних наблюдений за численностью и видовым составом водорослей, производимых на водозаборе очистных сооружений (ВОС) города Челябинска, мы сосредоточились на задаче оценки влияния изменения климата на развитие отдельных доминирующих видов фитопланктона. Для этого в первой части статьи демонстрируются некоторые наиболее значимые изменения численности диатомовых, зеленых и синезеленых водорослей, которые косвенно можно отнести к воздействию климатических факторов. Далее в каждом из отделов диатомовых, зеленых и синезеленых водорослей были выделены виды - индикаторы климатических изменений и индикаторы эвтрофикации, что позволило оценить вклад этих факторов в наблюдаемое изменение сукцессий. Под эвтрофикацией будем понимать процесс комплексного изменения экосистемы во- доема, связанный с увеличением его продуктивности, в том числе при обогащении водоемов питательными веществами, и проявляющийся в изменении структуры фитопланктона, главным образом его доминирующего комплекса, появлении в изменяющихся условиях новых доминирующих видов [10].

\section{ДАННЫЕ И МЕТОДЫ}

В статье использован архив еженедельных альгологических наблюдений ВОС города Челябинска, созданный гидробиологами В. А. Антиповой и А. О. Гаязовой (с 2012 года). Частота наблюдений была приблизительно еженедельной. Пробы отбирались между 8:00 и 9:00 местного времени из приемной камеры ВОС, находящейся на глубине 8 метров. Отбор проб сопровождался измерениями температуры воды и воздуха, измерением мутности и других характеристик. После фильтрации через мембрану с диаметром пор до 2 мкм пробы фиксировались $40 \%$ раствором формалина. Виды определялись под микроскопом с увеличением до 400 раз, а число клеток каждого вида подсчитывалось до 2011 года (после) с помощью счетной камеры Горяева (Нажотта) объемом 0,0009 $(0,01)$ мл. Результаты анализов заносились в журнал, затем эта информация была оцифрована. Вся выборка данных была разделена на первую (1984-1994), 
вторую (1995-2004) и третью (2005-2015) стадии. Это позволило по 30-50 пробам фитопланктона рассчитать среднемесячные характеристики отдельных видов.

В регионе, как и в целом в России, наблюдается потепление климата. Так, отмечается рост температур холодного периода Южного Урала с 1976 по 2005 более чем на $1{ }^{\circ} \mathrm{C}$ [3]. На основе обзоров Гидрометцентра нами установлено [5], что последние зимние и ранневесенние месяцы были самыми теплыми за столетие в Уральском округе.

Для достоверного ответа на вопрос, может ли региональное потепление стать причиной перестройки сукцессий фитопланктона, мы подготовили данные температур воздуха над водой и температур воды в точке отбора проб (1984-2015), а также данные температур воздуха, сумм осадков и скорости ветра на метеорологической станции Шершни (1984-2015), находящейся в 2 км севернее ВОС (рис. 1). Затем среднемесячные ряды $x(t)$ этих величин были преобразованы в безразмерные временные ряды $z$-оценок $Z(t)$ [8]. Ряд $Z(t)$ получается сравнением абсолютного отклонения $x(t)$ $\langle x\rangle$ некоторой метеорологической величины $x(t)$ в заданный момент времени $t$ от ее среднего $\langle x\rangle$ за период наблюдения по отношению к среднему квадратичному отклонению всей выборки $\sigma$ :

$$
Z(t)=\frac{x(t)-\langle x\rangle}{\sigma}
$$

Адекватное применение формулы (1) предполагает нормальность распределения месячных величин $x(t)$. Это в целом справедливо для температур и значений стандартного индекса осадков SPI [11] - полного аналога z-оценки (1). Индекс SPI был рассчитан официальным программным обеспечением [9], где гамма-распределение сумм осадков приводилось к нормальному распределению. Для удобства интерпретации мы модифицировали метод z-оценок, найдя разницу отклонения среднемесячных температур (SPI) двух последних стадий от температуры (SPI) первой стадии по отношению к отклонению $\sigma$. Такой же процедуре подверглись месячные ряды значений ветрового стресса, полученного осреднением квадратов скорости приземного ветра. Результаты анализа метеорологических параметров указанным методом представлены на рисунке 3 .

\section{ИЗМЕНЕНИЯ ЧИСЛЕННОСТИ ФИТОПЛАНКТОНА}

Всего с 1984 по 2015 год наблюдалось более 160 родов и видов планктонных водорослей, от- носящихся к семи отделам - Chlorophyta (77 видов), Bacillariophyta (31), Cyanophyta (17), Euglenophyta (11), Ochrophyta (11), Charophyta (10) и Miozoa (3). В сукцессии ШПВ преобладающую роль играют синезеленые $(72,9 \%)$, диатомовые $(18,8 \%)$ и зеленые $(7,2 \%)$ водоросли, определившие $99 \%$ общей численности фитопланктона за исследуемый период.

Для удобства изложения и анализа годовая сукцессия разделена на холодоводный и тепловодный сезоны вегетации. Первый сезон включает период с ноября по апрель, со средними температурами воды ниже $5^{\circ} \mathrm{C}$, когда водохранилище большую часть времени находится подо льдом. Второй сезон начинается после вскрытия льда в конце апреля и заканчивается с началом ледостава в ноябресезон открытой воды (май-октябрь).

Средние за стадию значения численности фитопланктона, его главных отделов и температур воды для холодных и теплых месяцев приведены в таблице 1 и таблице 2, а рисунок 2 качественно дополняет эту информацию.

Холодоводная сукцессия, как мы видим из таблицы 1 , характеризуется скачкообразным падением общей численности (ОЧ) в несколько раз от ноября к декабрю с минимумом в январе-марте и вновь скачкообразным ростом в апреле. Очевидно, что такой U-образный ход численности фитопланктона обусловлен уменьшением сезонной инсоляции и согласуется с установлением льда на ШПВ в первой половине ноября $\left(1,6-2^{\circ} \mathrm{C}\right)$, увеличением толщи льда от 40-50 см в декабре до 90100 см в марте и освобождением ото льда в середине апреля $\left(2,3-3^{\circ} \mathrm{C}\right)$. Видовой состав подледного фитопланктона при очень низких температурах $\left(0,9-1,6^{\circ} \mathrm{C}\right)$ заметно беднее - около трети общего числа видов.

Численность фитопланктона во второй и третьей стадии ШПВ (таблица 1) в среднем в 3-4 раза больше, чем в первой. Это увеличение было не равномерным: во второй стадии (1995-2004) численность подледного фитопланктона (декабрьмарт) не росла, зато в 1,5 (11) раз выросла ОЧ ноября (апреля). При чем главный вклад в рост численности в эти переходные месяцы внесло троекратное увеличение численности диатомовых водорослей (ДТ), тогда как численность зеленых (ЗЛ) и синезеленых (С3) практически не изменилась (таблица 1 и рис. 2).

Температура воды во второй стадии была на 0,3-0,5 ${ }^{\circ} \mathrm{C}$ выше, чем в предыдущее десятилетие. В последней стадии температура воды декабря-мар- 
Сукцессии фитопланктона холодоводного периода (ноябрь - апрель)

\begin{tabular}{|c|c|c|c|c|c|c|c|c|}
\hline Стадии & Отделы & Ноябрь & Декабрь & Январь & Февраль & Март & Апрель & Среднее $\times 10^{5}$ \\
\hline \multirow{5}{*}{ 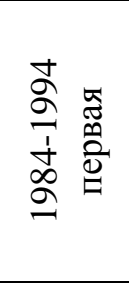 } & $\mathrm{O} 4 \times 10^{5}$ & 22,6 & 5,9 & 2,1 & 5,3 & 2,6 & 5,9 & 7,40 \\
\hline & $\mathrm{C} 3$ & $3 \%$ & $3 \%$ & $4 \%$ & $63 \%$ & $44 \%$ & $6 \%$ & 0,98 \\
\hline & ДТ & $85 \%$ & $86 \%$ & $69 \%$ & $28 \%$ & $43 \%$ & $60 \%$ & 5,33 \\
\hline & 3Л & $7 \%$ & $8 \%$ & $22 \%$ & $9 \%$ & $13 \%$ & $33 \%$ & $\mathbf{0 , 8 7}$ \\
\hline & $\mathrm{T},{ }^{\circ} \mathrm{C}$ & 1,54 & 1,29 & 1,14 & 1,38 & 1,44 & 2,35 & \\
\hline \multirow{5}{*}{ 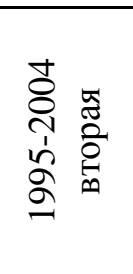 } & $\mathrm{OU} \times 10^{5}$ & 33,2 & 4,9 & 2,6 & 2,2 & 3,4 & 74,4 & 20,05 \\
\hline & $\mathrm{C} 3$ & $7 \%$ & $3 \%$ & $9 \%$ & $34 \%$ & $40 \%$ & $1 \%$ & 0,99 \\
\hline & ДТ & $85 \%$ & $84 \%$ & $80 \%$ & $54 \%$ & $44 \%$ & $93 \%$ & 17,60 \\
\hline & $3 \pi$ & $5 \%$ & $9 \%$ & $10 \%$ & $9 \%$ & $15 \%$ & $5 \%$ & 1,10 \\
\hline & $\mathrm{T},{ }^{\circ} \mathrm{C}$ & 2,13 & 1,52 & 1,58 & 1,56 & 1,69 & 3,03 & \\
\hline \multirow{5}{*}{ 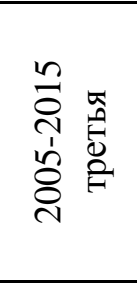 } & $\mathrm{OU} \times 10^{5}$ & 62,0 & 20,1 & 10,2 & 8,5 & 12,1 & 62,1 & 29,15 \\
\hline & $\mathrm{C} 3$ & $19 \%$ & $16 \%$ & $36 \%$ & $63 \%$ & $59 \%$ & $32 \%$ & 8,45 \\
\hline & ДТ & $69 \%$ & $64 \%$ & $39 \%$ & $17 \%$ & $16 \%$ & $26 \%$ & 13,20 \\
\hline & 3Л & $9 \%$ & $22 \%$ & $20 \%$ & $17 \%$ & $25 \%$ & $36 \%$ & 6,55 \\
\hline & $\mathrm{T},{ }^{\circ} \mathrm{C}$ & 1,76 & 0,90 & 0,91 & 0,92 & 0,94 & 2,53 & \\
\hline
\end{tabular}
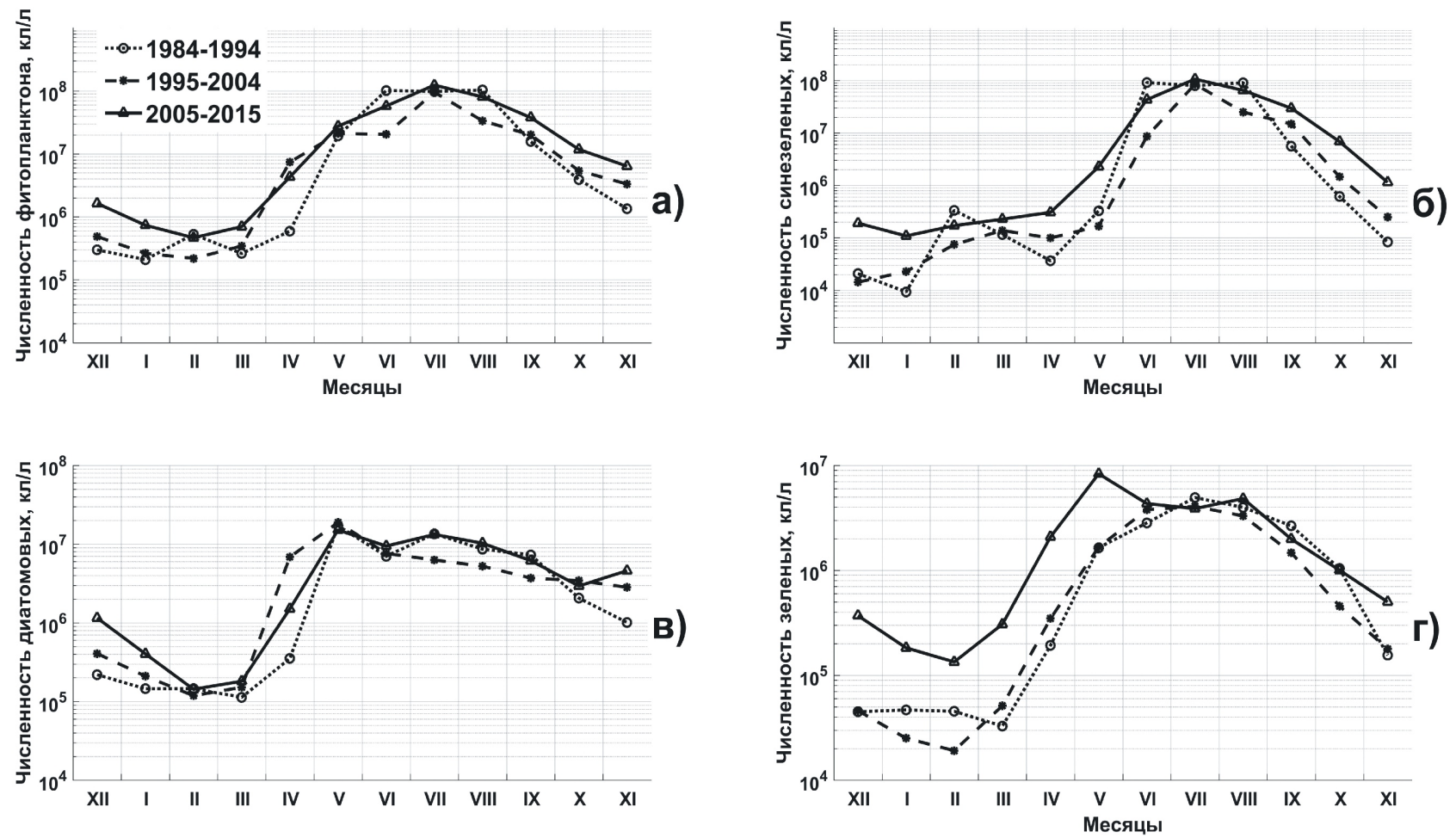

Puc. 2. Сезонной ход численности фитопланктона в различные стадии:

а) весь фитопланктон; б) синезеленые; в) диатомовые; г) зеленые

та наоборот стала на $0,5-0,6^{\circ} \mathrm{C}$ ниже, чем во второй стадии, и одновременно с этим в 6-8 раз выросла численность зеленых и синезеленых подледного периода, в сумме превысив численность зимних диатомей. Особенно значительным является рост численности зеленых (синезеленых) в декабре и апреле в 10 (20) и в 6 (27) раз, соответственно. На фоне уменьшения температур между второй и третьей стадией ШПВ произошла существенная перестройка холодоводного доминирую- 
Влияние климатической изменчивости на фитопланктонные комплексы Шерневского питьевого водохранилища (Южный Урал)

Таблица 2

Сукцессии фитопланктона тепловодного периода (май - октябрь)

\begin{tabular}{|c|c|c|c|c|c|c|c|c|}
\hline Стадии & Отделы & Май & Июнь & Июль & Август & Сентябрь & Октябрь & Среднее $\times 10^{7}$ \\
\hline \multirow{5}{*}{ 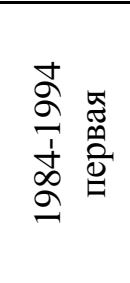 } & $\mathrm{OU} \times 10^{7}$ & 1,9 & 9,2 & 9,7 & 8,7 & 1,5 & 0,4 & 5,23 \\
\hline & $\mathrm{C} 3$ & $2 \%$ & $90 \%$ & $82 \%$ & $86 \%$ & $35 \%$ & $15 \%$ & 4,05 \\
\hline & ДТ & $88 \%$ & $7 \%$ & $13 \%$ & $9 \%$ & $47 \%$ & $55 \%$ & $\mathbf{0 , 8 7}$ \\
\hline & 3Л & $8 \%$ & $3 \%$ & $5 \%$ & $4 \%$ & $17 \%$ & $25 \%$ & 0,27 \\
\hline & $\mathrm{T},{ }^{\circ} \mathrm{C}$ & 8,38 & 17,95 & 20,46 & 19,50 & 13,43 & 6,75 & \\
\hline \multirow{5}{*}{ 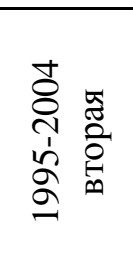 } & $\mathrm{OU} \times 10^{7}$ & 2,1 & 2,0 & 9,5 & 3,3 & 2,0 & 0,55 & 3,26 \\
\hline & $\mathrm{C} 3$ & $1 \%$ & $42 \%$ & $89 \%$ & $74 \%$ & $74 \%$ & $27 \%$ & 2,24 \\
\hline & ДТ & $89 \%$ & $37 \%$ & $7 \%$ & $16 \%$ & $19 \%$ & $64 \%$ & 0,75 \\
\hline & 3Л & $8 \%$ & $18 \%$ & $4 \%$ & $10 \%$ & $7 \%$ & $8,5 \%$ & 0,25 \\
\hline & $\mathrm{T},{ }^{\circ} \mathrm{C}$ & 10,75 & 18,43 & 21,03 & 19,26 & 13,45 & 6,20 & \\
\hline \multirow{5}{*}{ 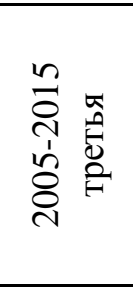 } & $\mathrm{OU} \times 10^{7}$ & 3,7 & 6,9 & 12,6 & 8,2 & 5,2 & 1,4 & 6,34 \\
\hline & $\mathrm{C} 3$ & $30 \%$ & $77 \%$ & $85 \%$ & $79 \%$ & $78 \%$ & $61 \%$ & 4,76 \\
\hline & ДТ & $42 \%$ & $15 \%$ & $11 \%$ & $13 \%$ & $14 \%$ & $22 \%$ & 1,02 \\
\hline & 3Л & $23 \%$ & $6 \%$ & $3 \%$ & $7 \%$ & $8 \%$ & $11 \%$ & 0,48 \\
\hline & $\mathrm{T},{ }^{\circ} \mathrm{C}$ & 12,33 & 18,98 & 20,61 & 19,61 & 13,55 & 6,51 & \\
\hline
\end{tabular}

щего комплекса при незначительном общем росте численности.

Изменения тепловодной сукцессии (таблица 2) не столь выражены, как в холодный период - снижение ОЧ в 1,6 раза во второй стадии компенсировалось ее ростом в 1,9 раза в третьей стадии. При этом однонаправленный рост общей численности в 2-3 раза обнаруживается только в мае, сентябре и октябре.

На рисунке 2г также заметен сдвиг максимальной численности зеленых с июня на май. Однако рост общей численности в мае, сентябре и октябре в основном обусловлен увеличением вклада синезеленых водорослей, которые явным образом стали доминантами осеннего планктона и вместе с зелеными потеснили диатомовые в мае. Растягивание сукцессии синезеленых хорошо заметно на рисунке 26.

Проведенный анализ временных рядов средней численности фитопланктона показал, что она хорошо описывается экспоненциальной зависимостью от времени. Действительно, положительные линейные тренды логарифмов общей численности и всех трех отделов фитопланктона в подледный период (с декабря по март) являются достоверными с коэффициентом корреляции $r \approx 0,7 \div 0,8 \pm 0,2$. К тому же достоверными, при $r \approx 0,8$, являются тренды логарифмов численности зеленых водорослей в апреле и мае. Синезеле- ные водоросли, несмотря на отмеченный весенний и осенний рост численности, имели значительные колебания численности от года к году, поэтому весной в апреле-мае, как и осенью в сентябре-ноябре, их тренды имели коэффициенты корреляции в диапазоне $r \approx 0,63 \div 0,65$. Достоверность летних изменений не превышает $r=0,55$.

\section{ИЗМЕНЕНИЕ КЛИМАТА РЕГИОНА}

О значимом весеннем потеплении и других изменениях климата в регионе свидетельствует годовой ход $Z$ оценок (рис. 3). Наиболее ярким и достоверным по сравнению с первой стадией событием является потепление мая, когда наблюдаются значения z-оценок температуры воздуха (рис. 3a) и воды (рис. 3б) $\geq 1$. Средняя температура воды в мае выросла почти на $4^{\circ} \mathrm{C}$ за 30 лет (таблица 2). Единственное естественное объяснение столь быстрого потепления воды - это более раннее освобождение поверхности водохранилища ото льда. Открытая вода, при растущей весенней инсоляции и высоких темпераурах воздуха, быстро аккумулирует значительный запас тепла. Это, в свою оцередь, ведет и к росту уровня температур воды в июне на $1^{\circ} \mathrm{C}$. В целом, этим же явлением объясняется более раннее развитие зеленых и синезеленых водорослей, имеющих одновременно все необходимые для этого компоненты: свет, тепло и поступление биогенов. 

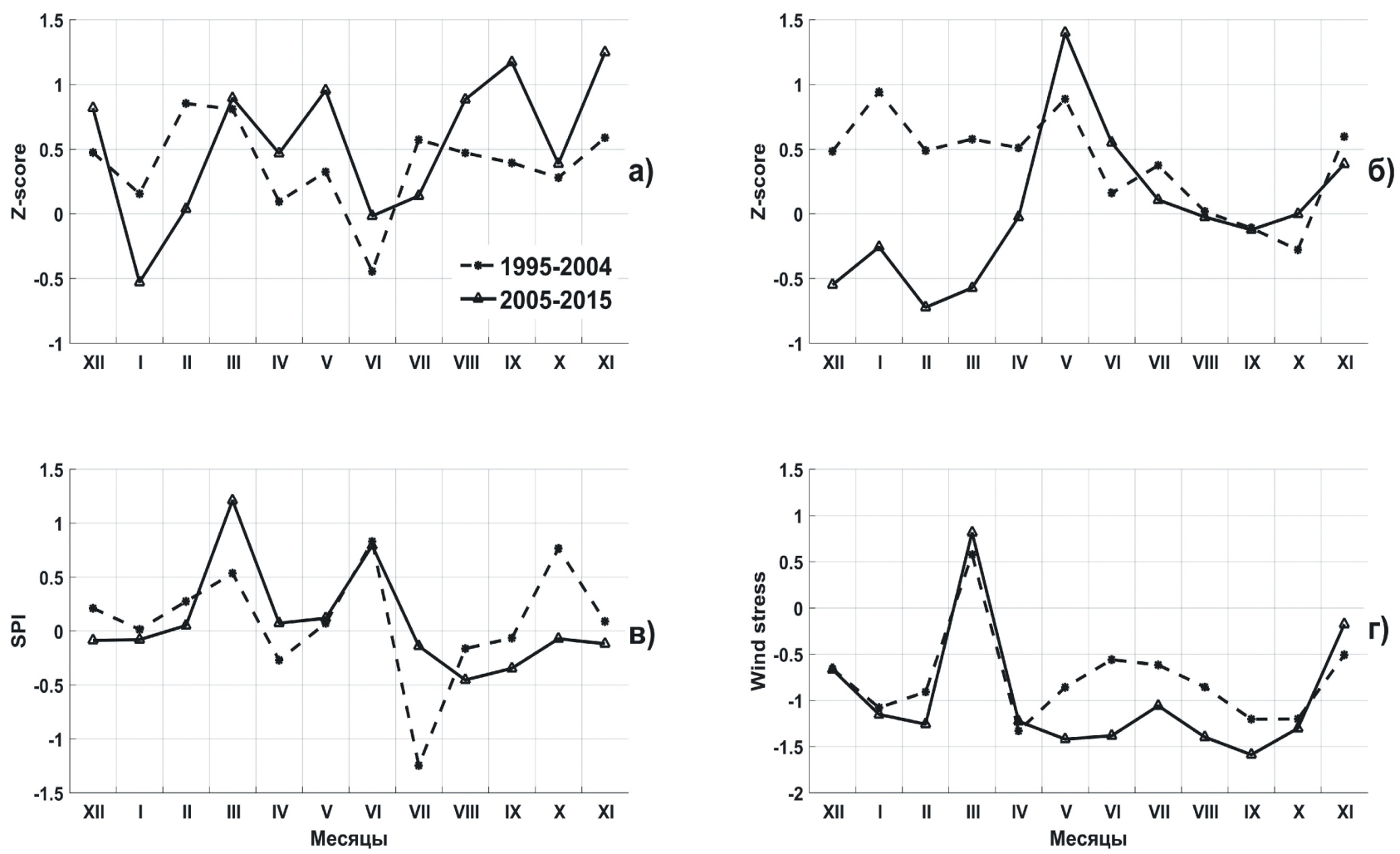

Puc. 3. Климатические изменения в районе водохранилища: а) $Z$ оценка температуры воздуха; б) температуры воды; в) стандартного индекса осадков (SPI) и г) ветрового стресса последних стадий (1995-2015) по отношению к периоду 1984-1994

Рисунок 3 также свидетельствует о достоверном изменении характера ранней весенней погоды Южного Урала: наблюдается увеличение температуры воздуха, осадков (рис. Зв) и скорости ветра (рис. Зг) в марте. Очевидно, что такое сочетание факторов - индикатор усиления циклонической активности. Заметим, что отсутствие изменений температур воды в августе-сентябре при низкой ветровой нагрузке ведет к повышению прибрежной температуры воздуха. С другой стороны, более высокие осенние температуры воздуха и продолжающееся выхолаживание водоема может объяснить наблюдаемое понижение температур воды.

Заметим, что уменьшение ветрового стресса в течение всего периода открытой воды (рис. 3г), возможно, способствует увеличению численности синезеленых водорослей, которым благоприятны условия слабого вертикального перемешивания [7, 11].

\section{ДОМИНАНТНЫЕ КОМПЛЕКСЫ ФИТОПЛАНКТОНА ШПВ}

Общеизвестно [10], что из 150-200 видов типичного водоема средних широт в каждой отдельно взятой пробе за $95 \%$ численности отвечают всего 6-8 видов. В свою очередь, эти массовые виды принадлежат к трем отделам, определяющим доминантные комплексы фитопланктона ШПВ. Поскольку развитие вида определяется его экологическими характеристиками, в том числе способностью к использованию климатических и питательных ресурсов, то оценка изменения численности этих видов может дать представление об изменении этих ресурсов. Представление о массовых видах и доминантных комплексах ШПВ дает таблица 3, полученная расчетом вклада родов и видов фитопланктона в общую численность отдела за референтное десятилетие с 1995 по 2004 год.

Доминантный комплекс диатомовых водорослей в сезон открытой воды (строки 1-4) и в целом за год определяется семейством стефанодисковых (Cyclotella radiosa и Cyclotella meneghiniana (+Stephanodiscus hantzschii), табеллариевых (Asterionella formosa) и летней Aulacoseira granulata (семейство Aulacoseiraceae). В подледный период Cyclotella sp. и Asterionella formosa остаются массовыми видами, но при общем снижении их численности в декабре-марте субдоминантами становятся перистые диатомеи.

Доминантный комплекс синезеленых водорослей (строки 5-8) определяется семействами (вида- 
Влияние климатической изменчивости на фитопланктонные комплексы Шерневского питьевого водохранилища (Южный Урал)

Таблица 3

Вклад доминирующих видов в сезонный ход численности отдела (\%)

\begin{tabular}{|r|l|r|r|r|r|r|r|r|r|r|r|r|r|r|}
\hline \multicolumn{1}{|c|}{ Месяцы } & 12 & 1 & 2 & 3 & 4 & 5 & 6 & 7 & 8 & 9 & 10 & 11 & $\begin{array}{c}\text { год } \\
\%\end{array}$ \\
\hline 1 & Cyclotella sp. & 53 & 46 & 41 & 53 & 96 & 91 & 69 & 45 & 30 & 58 & 50 & 29 & 68,1 \\
\hline 2 & Aulacoseira granulata & 1 & 2 & 3 & 3 & 1 & 2 & 11 & 42 & 64 & 31 & 4 & 1 & 16,9 \\
\hline 3 & Asterionella formosa & 36 & 31 & 18 & 12 & 1 & 5 & 10 & 4 & 1 & 7 & 40 & 61 & 9,5 \\
\hline 4 & Pennatae & 9 & 17 & 33 & 23 & 2 & 1 & 4 & 3 & 3 & 2 & 3 & 2 & 2,7 \\
\hline 5 & Aph. flos-aquae & 46 & 4 & 7 & 35 & 7 & 22 & $\mathbf{7 0}$ & $\mathbf{8 0}$ & $\mathbf{4 7}$ & $\mathbf{5 8}$ & $\mathbf{7 6}$ & 35 & 72,5 \\
\hline 6 & Anabaena flos-aquae & 4 & 5 & 3 & 7 & 4 & 10 & 24 & 13 & 14 & 1 & 4 & 11 & 13,0 \\
\hline 7 & Microcystis + Gloeocapsa & 20 & 11 & 2 & 12 & 2 & 55 & 5 & 4 & 36 & 36 & 10 & 50 & 11,9 \\
\hline 8 & Phormidium mucicola & 27 & 76 & 78 & 41 & 47 & 1 & 0 & 0 & 1 & 1 & 0 & 1 & 0,3 \\
\hline 9 & $\begin{array}{l}\text { Monoraphidium + } \\
\text { Ankistrodesmus }\end{array}$ & 57 & 53 & 54 & 32 & 12 & 64 & 43 & 22 & 29 & 39 & 38 & 41 & 37,1 \\
\hline 10 & $\begin{array}{l}\text { Scenedesmus, +Coelastrum } \\
\text { и Tetrastrum }\end{array}$ & 14 & 24 & 24 & 13 & 4 & 12 & 30 & 30 & 30 & 32 & 26 & 24 & 27,0 \\
\hline 11 & Chlamydomonadaceae & 7 & 2 & 6 & 42 & 69 & 14 & 1 & 2 & 2 & 2 & 2 & 9 & 5,5 \\
\hline
\end{tabular}

ми) Aphanizomenonaceae (Aphanizomenon flosaquae), Anabaenaceae (Anabaena flos-aquae), Microcystaceae (Microcystis aeruginosa Gloeocapsa turgida, G. limnetica). В подледный период доминантами становятся формидиевые (Phormidium mucicola). Заметим, что в отдельные годы наблюдались вспышки Planktothrix agardhii, Gomphosphaeria lacustris, Merismopedia minima, которые временно меняли сценарий, описанный в таблице 3.

Доминантный комплекс зеленых водорослей (строки 9-11) по числу семейств обширнее, чем комплексы диатомовых и синезеленых. Здесь основными являются семейства Selenastraceae (массовый вид Monoraphidium contortum с небольшой добавкой других видов рода Monoraphidium и Ankistrodesmus) и Scenedesmaceae (Scenedesmus ellipticus, Scenedesmus qudricauda), сопровождаемые видами рода Coelastrum и Tetrastrum. Ранней весной доминантами являются представители рода Chlamydomonas. Следует сказать, что в июле и августе важными является семейство Hydrodictyaceae (род Pediastrum, род Tetraedron $-8,5 \%$ годовых), а в декабре-марте Trebouxiophycea (род Crucigenia $-5,8 \%$ годовых). В сезон открытый воды постоянно встречается Oоcystaceae (Oocystis, Lagerheimia).

\section{ИЗМЕНЕНИЕ ЧИСЛЕННОСТИ МАССОВЫХ ВИДОВ}

Для демонстрации характерных изменений, произошедших за тридцать лет, выбраны синезеленые: Aphanizomenon flos-aquae (Aph. flos-aquae, рис. 4a), Anabaena flos-aquae (An. flos-aquae, pис. 4б), Microcystis aeruginosa (M. aeruginosa, pис. 4в), а также Planktothrix agardhii (P. agardhii, рис. 4г) - неожиданный доминант комплекса синезеленых ШПВ последних лет [5, 13].

Сезонный ход численности основного доминанта Шершневского водохранилища Aph. flosaquae за последние тридцать лет изменился незначительно (рис. 4а). Действительно, если принять численность первой стадии за единицу, динамику изменений можно выразить как $1 \rightarrow 1,2 \rightarrow 1,3$. An. flos-aquae к настоящему моменту увеличила свою численность в три раза $(1 \rightarrow 2,2 \rightarrow 3)$. Из рисунка 4 видно, что наиболее значимое ее увеличение наблюдалось в подледных пробах средней стадии (в 2,5 раза) и в мае-июне последней стадии (в 4,8 раза).

Наиболее показательный рост численности демонстрируют $M$. aeruginosa $(1 \rightarrow 1,9 \rightarrow 4,1)$ и P. Agardhii $(1 \rightarrow 8 \rightarrow 98)$. При этом численность первого вида в подледный период росла как $1 \rightarrow 30 \rightarrow 300$, а вегетационный период $M$. aeruginosa растянулся на весь год (рис. 4в), что определило сглаживание вегетационного периода всего отдела синезеленых (рис. 2a). Феноменальный рост численности $P$. agardhii связан с тем, что в первую стадию она единично обнаружена в июле, в среднюю стадию (рис. 4г) уже встречалась круглогодично, а современная стадия характеризуется круглогодичной вегетацией водоросли с плавным увеличением (снижением) численности от зимы к лету (от лета к осени). В особенно дождливый и прохладный 2015 год $P$. agardhii вышла на доминирующие позиции [7]. 

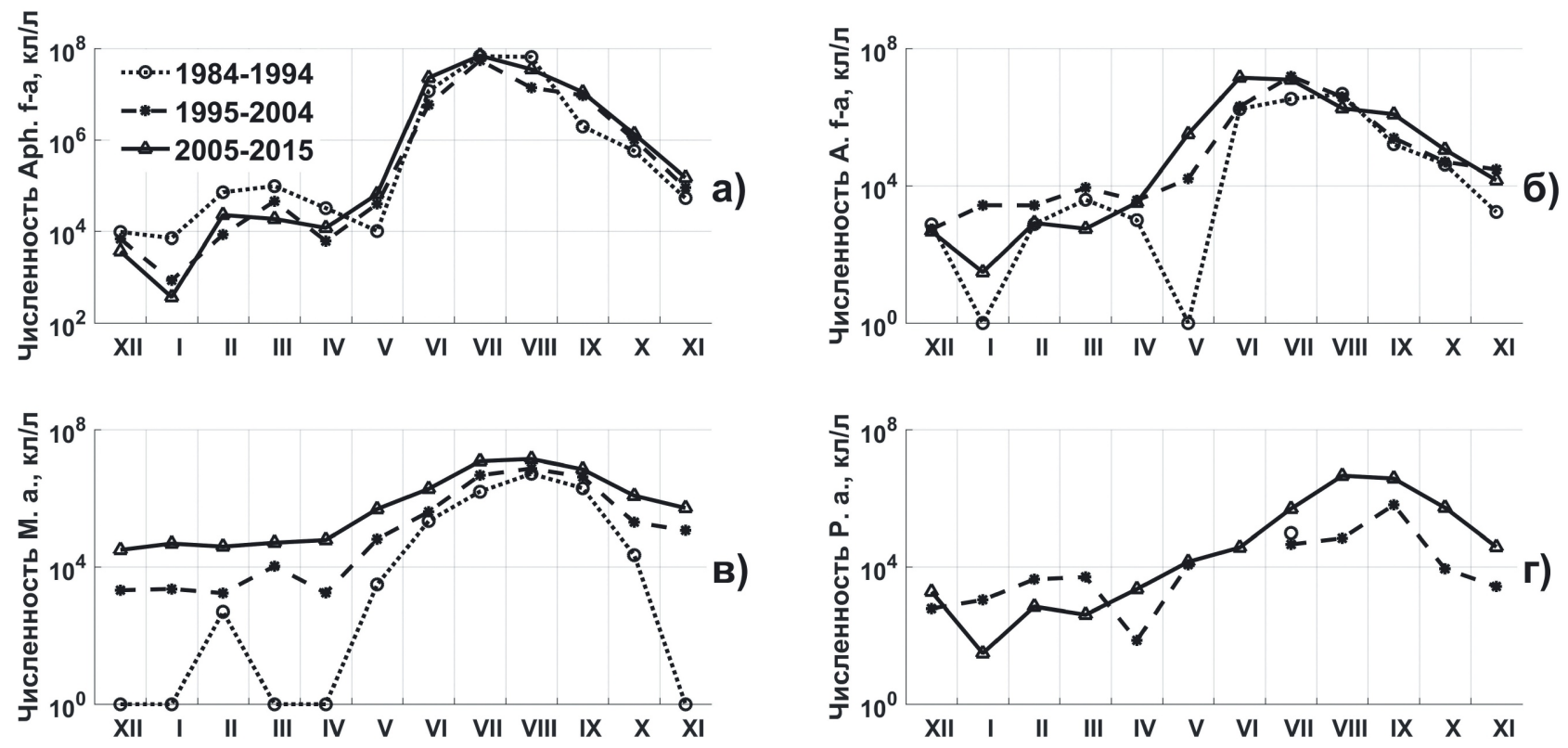

Puc. 4. Сукцессии массовых видов синезеленых водорослей: а) Aph. flos-aquae; б) A. flos-aquae;

в) M. aeruginosa; г) P. agardhii

Сезонная сукцессия массовых видов зеленых Scenedesmus quadricauda, Chlamydomonas sp., Monoraphidium contortum (рис. 5а, в, д) и диатомовых Aulacoseira granulata, Fragilaria crotonensis и Asterionella formosa (рис. 5б, г, е) также сильно изменилась за три десятилетия. При этом необходимо отметить, что сукцессия представителей доминантного семейства стефанодисковых изменилась незначительно, поэтому и не представлена на рисунке 5.

Scenedesmus quadricauda, обитатель хорошо освещенных мелких водоемов и водотоков [10], значительно снизил свою численность в период открытой воды (рис. 5а), что косвенно говорит об ухудшении условий освещенности. Его численность с июня по ноябрь уменьшилась по отношению к численности первой стадии в 2,5 и 3,5 раза. Напротив, численность устойчивой к световому дефициту типично летней диатомеи Aulacoseira granulata (рис. 4б) увеличилась в летние месяцы (май-август) последней стадии в 2,5 раза по отношению к первой стадии, что на фоне снижения численности Scenedesmus, а также водорослей из рода Pediastrum, говорит о возможном увеличении мутности и снижении освещенности.

Численность Chlamydomonas (рис. 5в), известных индикаторов органического загрязнения, увеличилась в подледный период и особенно велика сразу после начала паводка, когда вода насыщена питательными веществами. Численность диатомовых A. formosa $(1 \rightarrow 1,5 \rightarrow 2,5)$ и Fragilaria croto- nensis $(1 \rightarrow 0,8 \rightarrow 16)$ также значительно выросла в подледный период последней стадии. Численность $M$. contortum увеличивалась $(1 \rightarrow 3,0 \rightarrow 8,5)$ и определила сезонную динамику общей численности зеленых водорослей в подледный период и в целом за год, а также сдвиг пика численности отдела зеленых на май.

\section{ИЗМЕНЕНИЕ ИНДЕКСА САПРОБНОСТИ}

Изменение трофического статуса водоема, как правило, подразумевает расчет индекса сапробности, в основе которого лежат известные свойства отдельных организмов-индикаторов обитающих в водоемах с различной степенью органического загрязнения. Поскольку при эвтрофикации помимо увеличения уровня органического загрязнения, происходит ряд других изменений условий обитания планктона, в нашей статье за основу взята система альгогруппировок Рейнольдса, описывающая условия обитания фитопланктона в целом, в том числе в водоемах различной степени трофности $[10,12]$. Тем не менее, для сопоставления результатов был рассчитан индекс сапробности по стандартной формуле Пантле-Букка, значения сапробной валентности массовых видов взяты из справочника [11]. На рисунке 6 представлен график, иллюстрирующий сезонные изменения индекса на разных стадиях жизни ШПВ. Как ни парадоксально, но индекс сапробности оказался выше в первую стадию жизни ШПВ, самые низкие его значения отмечаются в среднюю стадию. Как видим, увеличение индекса в современную стадию по 

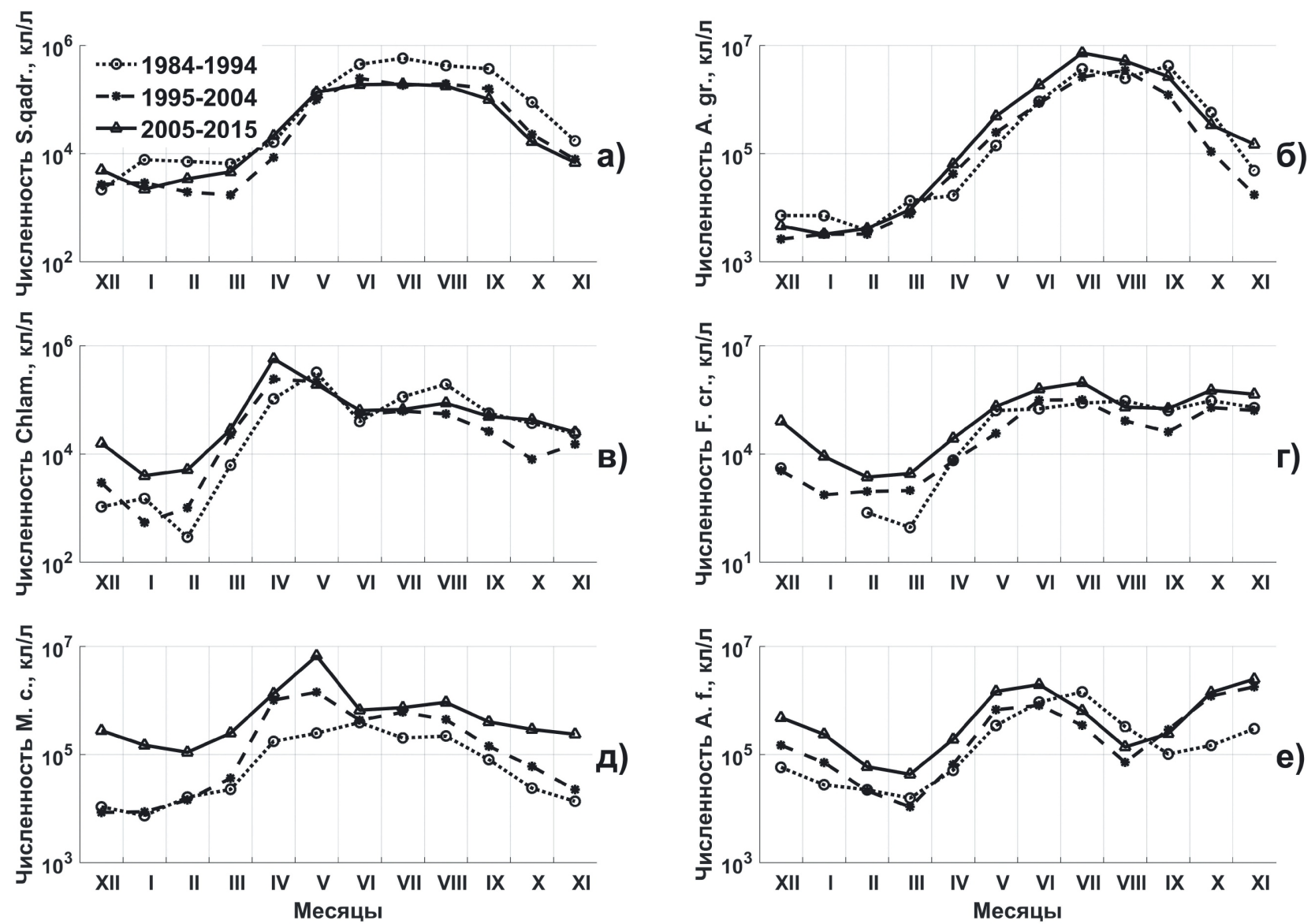

Puc. 5. Сукцессии массовых видов диатомовых и зеленых водорослей: а) S. quadricauda; б) A. granulata; в) Chlamydomonas sp.; г) F. crotonensis; д) M. contortum; е) A. formosa

сравнению с первой отмечается только в мае и декабре, в остальные же месяцы индекс был ниже. Майское увеличение индекса, по-видимому, объясняется активным развитием $M$. contortum, имеющей достаточно высокую сапробную валентность 2,2 . В целом же, индекс менялся от периода к периоду незначительно. Наиболее существенные изменения отмечаются в осенние и зимние месяцы - с сентября по февраль.

Увеличение численности A. formosa, имеющей сапробную валентность, равную 1 , а также сокращение численности $S$. quadricauda с сапробной валентностью 2 , по-видимому, сказалось на уменьшении сапробного индекса в стадиях 1995-2004 и 2005-2015. Низкие значения индекса в ноябре, декабре и январе средней стадии можно объяснить снижением в эти месяцы численности A. granulata с высокой сапробной валентностью 2,4 , а более высокие значения индексов в октябре-феврале последнего периода по сравнению с аналогичными значениями средней стадии, вероятно, связаны с более интенсивным развитием в последней стадии F. crotonensis с сапробной валентностью 2,7.

\section{ОБСУЖДЕНИЕ РЕЗУЛЬТАТОВ}

Климатические изменения в сезон открытой воды выражаются в постепенном увеличении средней температуры воды в мае и июне. Так, в мае первого периода средняя температура воды составляла $8,4^{\circ} \mathrm{C}$, в стадию $1994-2004$ достигла $10,75^{\circ} \mathrm{C}$ и наконец, к настоящему периоду она составила уже $12,3^{\circ} \mathrm{C}$ (таблица 2). Изменения июньских температур менее выражено, средняя температура июня в настоящий период на градус выше по сравнению с первой стадией.

На этом фоне численность фитопланктона в мае к настоящему периоду увеличилась почти в 2 раза (таблица 2), при этом, по сравнению с первым периодом, существенно увеличился вклад в общую численность фитопланктона синезеленых (в 15 раз), а также зеленых водорослей (в 2,9 раза). За счет значительного увеличения численности синезеленых и зеленых в мае снизился относительный вклад диатомей - основных доминантов весеннего фитопланктона (в 2,1 раза), однако при этом значение их абсолютной численности не изменилось. 


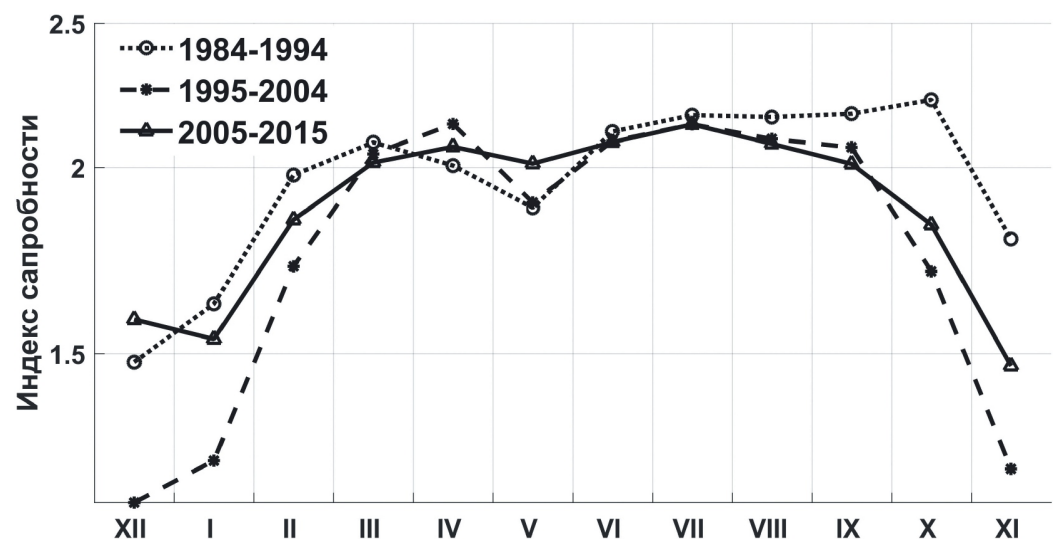

Puc. 6. Сезонное изменение индекса сапробности (в расчете на массовые виды)

Учитывая, что существенные изменения температуры, показанные для мая месяца, подтверждаются и при анализе $z$-оценок рядов температуры воды (рис. 3б), а также при анализе рядов температур воздуха (рис. 3a), можно связать майскую сукцессионную перестройку с температурным оптимумом большинства видов. Так, среди массовых видов синезеленых и зеленых водорослей преобладают виды, для интенсивного развития которых благоприятно увеличение майских температур (синезеленые Aph. flos-aquae, A. flos-aquae pис. 4a, б; зеленые M. contortum, Chlamydomonas $s p .-$ рис. 5 в, д). Таким образом, как следствие климатических изменений в регионе, мы наблюдаем майский пик численности зеленых водорослей и раннее начало вегетации синезеленых водорослей.

В летний период отмечаются и другие сукцессионные перестройки, которые сложно объяснить фактором температуры воды, а именно: к среднему периоду в месяцы открытой воды существенно увеличилась численность зеленой водоросли Scenedesmus quadricauda, а затем, к настоящему периоду, снова снизилась, достигнув уровня первой стадии (рис. 5a). Снижение численности этого индикатора эвтрофных условий, предпочитающего хорошо освещенные водоемы, может говорить об изменении условий освещенности в последней стадии на фоне конкурентных отношений с видами, массовое развитие которых создает условия светового дефицита для других видов. Так, способные регулировать свое положение в толще воды колонии синезеленых, в том числе M. aeruginosa, A. flos-aquae, P. agardhii, cyщественно поднявшие свою численность в летние месяцы последнего периода (рис. 4б, в, е), возможно, создали условия светового дефицита для требовательных к свету видов зеленых водорослей, таких как S. quadricauda, Pediastrum duplex,
Coelastrum microporum, что привело к закономерному снижению их численности и более интенсивному развитию видов более устойчивых к условиям освещения, например, диатомеи Aulacoseira granulata, численность которой в летние месяцы последнего десятилетия, напротив, увеличилась (рис. 5б).

В холодноводный период также наблюдаются значительные изменения температуры воды. Наиболее теплой является средняя стадия с температурой воды в среднем на $0,3-0,5^{\circ} \mathrm{C}$ выше, чем в предыдущее десятилетие, а в подледную стадию 2005-2015, напротив, наблюдается снижение средних месячных температур по сравнению с первой стадией (таблица 1). Увеличение зимних температур воды периода 1995-2004 сказалось на увеличении численности диатомовых водорослей, тогда как численность водорослей остальных отделов изменилась незначительно. После некоторого снижения зимних температур в последнем периоде рост численности подледного фитопланктона продолжился, но теперь в основном за счет синезеленых и зеленых водорослей (холодоустойчивые виды M. aeruginosa, рис. 4в и M. contortum, рис. 5д), численность диатомей при этом хоть и уменьшилась, но осталась достаточно высокой по сравнению с первым периодом.

Некоторое потепление зимних температур в средней стадии, возможно, дало толчок к более интенсивному развитию диатомей, главным образом A. formosa и F. crotonensis (таблица 3, рис. 5 e, г). Однако увеличение численности этих обитателей эвтрофных перемешиваемых водоемов $[10,12]$ можно также связать и с изменением его трофического статуса. К тому же дальнейшее увеличение численности фитопланктона даже на фоне снижения зимних температур воды в основном за счет синезеленой $M$. aeruginosa и зеленой $M$. 
contortum, также обитающих в эвтрофных условиях $[10,12]$, однозначно говорит о доступности биогенных веществ в зимний период.

Результаты сапробиологического анализа (рис. 6) нельзя считать удовлетворительными. Диатомовая $A$. formosa может обитать как в чистых, так и в высокоэвтрофных водоемах, а развитие «классических» индикаторов сапробности из отдела зеленых водорослей подавляется при массовом развитии синезеленых водорослей. Сокращение численности «классических» индикаторов сапробных условий и увеличение численности «условно чистых», например A. formosa, по-видимому, привело к существенному занижению индексов сапробности в последние стадии жизни ШПВ. В целом, от стадии к стадии индекс изменяется незначительно (в пределах третьего класса качества) и не дает внятной картины изменений экосистемы ШПВ.

Таким образом, более важными представляются общее увеличение численности водорослей всех отделов, как явный признак возросшей продуктивности водоема, и трансформация фитопланктонного сообщества - замена одних массовых видов другими, более приспособленными к изменившимся условиям.

В условиях климатических изменений прослежен отклик фитопланктонных сообществ, развивающихся в природных условиях на примере озер бассейна среднего течения р. Ворона в пределах особо охраняемой природной территории заповедника «Воронинский». Данные, полученные Г.А. Анциферовой и другими исследователями, подтверждают авторские выводы о сукцессионных перестройках сообществ фитопланктона, причем на примере водоемов ООПТ, при ограничении антропогенных нагрузок, но при повышенных летних температурах воздуха (2010-2012 годы) $[1,2]$.

Наблюдаемые нами сукцессионные перестройки, выражающиеся в массовом развитии одних видов и вытеснении других, - это отклик на комплекс изменений условий водной среды, связанный как с климатическими изменения, так и с антропогенным увеличением насыщенности среды элементами питания.

\section{ЗАКЛЮЧЕНИЕ}

Изучение многолетних изменений численных характеристик фитопланктонного сообщества позволяет заключить: последнее десятилетие характеризуется растягиванием вегетационного периода синезеленых водорослей, динамика их численности становится более сглаженной, что является признаком наличия благоприятных условий для развития водорослей в течение всего года и прямым следствием ускорения эвтрофикации Шершневского водохранилища. В подледный период последней стадии активно вегетирует зеленая водоросль $M$. contortum, также получающая достаточно питания в зимний период. Увеличила свою численность в подледный период и индикатор эвтрофных условий $[10,12]$ диатомовая $A$. formosa, а также устойчивая к низким температурам синезеленая M. aeruginosa.

Достоверное увеличение средней температуры воды весной 2005-2015 годов дает основание полагать, что майский пик численности M. contortum и раннее начало вегетации синезеленых связано с климатическими изменениями региона. Увеличение численности $M$. contortum и других индикаторов эфтрофных условий, подледную вегетацию синезеленых водорослей следует считать результатом насыщения воды азотистыми веществами, вероятно, вследствие несанкционированных сбросов сточных вод близлежащими поселками и жилыми районами.

\section{СПИСОК ЛИТЕРАТУРЫ}

1. Анализ космических снимков как метод контроля природных и антропогенных процессов на примере среднего течения Вороны (Тамбовская область) / С. Л. Шевырев [и др.] // Вестник Воронежского государственного университета. Сер. География. Геоэкология. - 2013. - № 1. - С. 35-39.

2. Анциферова Г. А. Особенности вегетационных сукцессий в условиях аномально высоких летних температур 2010-2012 годов (бассейн среднего Дона) / Г. А. Анциферова // Вестник Воронежского государственного университета. Сер. География. Геоэкология. - 2013. - № 2. - C. 107-162.

3. Водоросли. Справочник / под ред. С. П. Вассера [и др.]. - Киев : Наукова Думка, 1989. - 608 с.

4. Гаязова А. О. О трансформации доминантного комплекса фитопланктонного сообщества Шершневского питьевого водохранилища в 2015 году / А. О. Гаязова, С. М. Абдуллаев // Научный поиск : материалы 8-й научной конференции аспирантов и докторантов. Естественные науки. - Челябинск : Издательский центр ЮжноУральского государственного университета, 2016. C. $97-104$.

5. Гаязова А. О. Сукцессии массовых видов водорослей Шершневского водохранилища в многолетней ретроспективе / А. О. Гаязова, С. М. Абдуллаев // Биоиндикация в мониторинге пресноводных экосистем : материалы III международной конференции. - СанктПетербург, 2017. - С. 76-80.

6. Ленская О. Ю. Особенности текущих климатических изменений в регионе Южного Урала / О. Ю. Лен- 
ская, М. Г. Ботова // Вестник Челябинского государственного университета. - 2011. - № 5. - С. 44-49.

7. Сиренко Л. А. Физиологические основы размножения синезеленых водорослей в водохранилищах / Л. А. Сиренко. - Киев : Наукова думка, 1972. - 203 с.

8. Agricultural meteorological data, their presentation and statistical analysis // Guide to Agricultural Meteorological Practices. WMO-No. 134. - World Meteorological Organization. - Geneva, 2010.

9. Program to Calculate Standardized Precipitation Index [Electronic resource] : [The National Drought Mitigation Center / University of Nebraska-Lincoln]. Access: http://drought.unl.edu/MonitoringTools/ DownloadableSPIProgram.aspx (Thursday, January 10, 2018).

10. Reynolds C. S. The ecology of phytoplankton / C. S. Reynolds. - Cambridge : University press. - 2006. $535 \mathrm{p}$.

11. Standardized Precipitation Index User Guide. WMO-No. 1090 / World Meteorological Organization. Geneva, 2012.

12. Towards a functional classification of the freshwater phytoplankton / C. S. Reynolds [et al.] // Journal of Plankton Research. - 2002. - Vol. 24, No. 5. - P. 417-428.

13. Wacklin P. Biodiversity and Phylogeny of Planktic Cyanobacteria in Temperate Freshwater Lakes: doctoral dissertation (article-based) / P. Wacklin. - Helsinki, 2006. $-69 \mathrm{p}$.

\section{REFERENCES}

1. Analiz kosmicheskikh snimkov kak metod kontrolya prirodnykh i antropogennykh protsessov na primere srednego techeniya Vorony (Tambovskaya oblast') / S. L. Shevyrev [i dr.] // Vestnik Voronezhskogo gosudarstvennogo universiteta. Ser. Geografiya. Geoekologiya. 2013. - № 1. - S. 35-39.

2. Antsiferova G. A. Osobennosti vegetatsionnykh suktsessiy v usloviyakh anomal'no vysokikh letnikh temperatur 2010-2012 godov (basseyn srednego Dona) / G. A. Antsiferova // Vestnik Voronezhskogo gosudarstvennogo universiteta. Ser. Geografiya. Geoekologiya. - 2013. - № 2. - S. 107-162.

3. Vodorosli. Spravochnik / pod red. S. P. Vassera [i dr.]. - Kiev : Naukova Dumka, 1989. - 608 s.

Гаязова Анна Олеговна

аспирант Южно-Уральского государственного университета, г. Челябинск, E-mail: why.ann@ mail.ru

\section{Абдуллаев Санжар Муталович}

доктор географических наук, профессор кафедры системного программирования Южно-Уральского государственного университета, г. Челябинск, E-mail: abdullaevsm@susu.ru
4. Gayazova A. O. O transformatsii dominantnogo kompleksa fitoplanktonnogo soobshchestva Shershnevskogo pit'evogo vodokhranilishcha v 2015 godu / A. O. Gayazova, S. M. Abdullaev // Nauchnyy poisk : materialy 8-y nauchnoy konferentsii aspirantov i doktorantov. Estestvennye nauki. - Chelyabinsk : Izdatel'skiy tsentr Yuzhno-Ural'skogo gosudarstvennogo universiteta, 2016. - S. 97-104.

5. Gayazova A. O. Suktsessii massovykh vidov vodorosley Shershnevskogo vodokhranilishcha v mnogoletney retrospektive / A. O. Gayazova, S. M. Abdullaev // Bioindikatsiya $\mathrm{v}$ monitoringe presnovodnykh ekosistem : materialy III mezhdunarodnoy konferentsii. - Sankt-Peterburg, 2017. - S. 76-80.

6. Lenskaya O. Yu. Osobennosti tekushchikh klimaticheskikh izmeneniy v regione Yuzhnogo Urala / O. Yu. Lenskaya, M. G. Botova // Vestnik Chelyabinskogo gosudarstvennogo universiteta. - 2011. - № 5. - S. 44-49.

7. Sirenko L. A. Fiziologicheskie osnovy razmnozheniya sinezelenykh vodorosley v vodokhranilishchakh / L. A. Sirenko. - Kiev : Naukova dumka, 1972. - 203 c.

8. Agricultural meteorological data, their presentation and statistical analysis // Guide to Agricultural Meteorological Practices. WMO-No. 134. - World Meteorological Organization. - Geneva, 2010.

9. Program to Calculate Standardized Precipitation Index [Electronic resource] : [The National Drought Mitigation Center / University of Nebraska-Lincoln]. - Access: h t t p://drought.un 1.edu/Monitoring Tools/ DownloadableSPIProgram.aspx (Thursday, January 10, 2018).

10. Reynolds C. S. The ecology of phytoplankton / C. S. Reynolds. - Cambridge : University press. - 2006. $535 \mathrm{p}$.

11. Standardized Precipitation Index User Guide. WMO-No. 1090 / World Meteorological Organization. Geneva, 2012.

12. Towards a functional classification of the freshwater phytoplankton / C. S. Reynolds [et al.] // Journal of Plankton Research. - 2002. - Vol. 24, No. 5. - P. 417-428.

13. Wacklin P. Biodiversity and Phylogeny of Planktic Cyanobacteria in Temperate Freshwater Lakes: doctoral dissertation (article-based) / P. Wacklin. - Helsinki, 2006. $-69 \mathrm{p}$.

\section{Gayazova Anna Olegovna}

Postgraduate student of the South Ural State University, Chelyabinsk, E-mail: why.ann@mail.ru

Abdullaev Sanjar Mutalovitch

Doctor of Geographical Sciences, Professor of the Department of system programming of the South Ural State University, Chelyabinsk, E-mail: abdullaevsm@susu.ru 